\title{
The Institute of Hygiene and Tropical Medicine of Lisbon and its Research in Medical Microbiology
}

\section{${\text { Fernando } \text { Teles }^{1 *} \text { and Maria Luísa Vieira }}^{2}$}

${ }^{1}$ Member of the organizing commission of the "2nd National Congress of Tropical Medicine"

${ }^{2}$ Director of the Unit of Medical Microbiology of the IHMT

The Institute of Hygiene and Tropical Medicine (IHMT; http:// www.ihmt.unl.pt) ranks among the oldest and more prestigious European schools dedicated to tropical science. Its centenary history strongly overlaps with an important part of the colonial history of Portugal and even of Europe. The pertinence of such an institution as a part of the Portuguese colonial endeavors may be assigned to the first half of the $19^{\text {th }}$ century, when, following the independence of Brazil and in the middle of tough disputes with the biggest colonizing powers in Europe (namely Germany and United Kingdom) for the possession and domain of its African territories, a national consciousness and pressure for the establishment of "civilizing stations" throughout the Portuguese African empire began to emerge [1]. By this time, it was recognized that no successful fixation of European colonists would be possible without prior control of the biggest tropical endemics that afflicted entire populations in the overseas' colonies. The specialty of Tropical Medicine, mainly practiced by military doctors, was beginning to be seen as an indispensable complement of the colonization efforts. Indeed, the former Minister of the British colonies Joseph Chamberlain well translated this concern, by stating that "the fight against tropical diseases constitutes the real basis of the politics of colonization" [2]. The important biomedical discoveries in the field of Tropical Medicine by the late $19^{\text {th }}$ century led to the need for developing and deepening the research and teaching of this medical branch and, ultimately, to the creation, all across Europe, of several schools of Tropical Medicine: Liverpool, London (both in 1899), Hamburg (1900) and Lisbon (1902). Until 1935, the designation of 'School' well matched the essential role of the institution in providing support for healthcare in the tropical colonies of the Portuguese empire, aligned with the activities of the closely-located Colonial Hospital of Lisbon. This was carried out not only by the 'indoors' activities, but also through permanent and temporary working missions to the colonial territories; these missions assumed a predominant feature of headship in Africa and of advisory in Asia. After 1935, the Institute became formally named as 'Institute of Tropical Medicine.' This shifting of the name from 'School' to 'Institute' corresponded to an increasing focus on teaching and research activities, attributes that resemble those of a university institution. During its long story, several internationally renowned entities in the field of Tropical Medicine taught and researched in the Institute, some of them even becoming directors. Some of these personalities were Ayres Kopke (one of the Institute's founders), João Fraga de Azevedo, Francisco Cambournac (appointed in 1954, for the position of Director-General of the WHO for Africa) and Aldo Castellani (world-top specialist in the field of Tropical Medicine, he began to teach in the Institute in 1947). In 1958, the VI ${ }^{\text {th }}$ Congress of Tropical Medicine and Malaria took place in the Institute, with the presence of many representatives from international organizations working in Tropical Medicine. It has been argued that the enormous success of this event was perceived in the Portuguese colonies and that such prestigious image rendered undeniable benefits even during the hard periods of active war for independence of the African colonies, when the working missions of the Institute were always allowed to circulate freely and to tackle their field tasks [2]. In 1972, the current 'Institute of Hygiene and Tropical
Medicine' was finally created by a governmental law. After successive tutelages by the Ministries of Overseas and of Health, the IHMT was finally integrated in the New University of Lisbon (Universidade Nova de Lisboa) in 1980 and, as such, under the tutelage of the Ministry of Education and Science. This corresponded to a strengthening of its role as a university institution with a tropical vocation. In the years immediately after the decolonization period, there were some natural concerns about the future of the Institute regarding its relation with the new politically emancipated territories and the accomplishment of its original tropical vocations. However, we may say that the Institute has found, over these last decades, a natural position of collaborating institution with a tropical world full of ancient health specificities that persisted (some of them may have even grown in importance and severity) upon the advent of decolonization. In short, the IHMT is nowadays an essential player in the Portuguese cooperation policy for health, especially in terms of cooperation for development, with the Portuguese-speaking African world, but also with Brazil and EastTimor.

Nowadays, the activities of the IHMT essentially comprise teaching and research in biomedical sciences and in public health, cooperation in health for development and services to the community. Taking into account the essential nature of university institution, teaching and research may well be considered the core areas of IHMT's activity; in fact, many of our researchers and teachers are directly involved with biomedical sciences, spanning the specific areas of parasitology, bacteriology, virology and mycology. The research covers fundamental aspects of pathogen and vector biology and of their interactions with the hosts, but also strategies to combat infectious diseases, namely in terms of prophylaxis (e.g., vaccine design), diagnosis (conventional, molecular and new approaches) and therapeutics, in this regard with particular emphasis in biochemical and biological mechanisms to circumvent antimicrobial drug resistance.

In April of 1952, in Lisbon, the " $1^{\text {st }}$ National Congress of Tropical Medicine" took place, as part of the celebrations of the $50^{\text {th }}$ anniversary of the so-called Institute of Tropical Medicine and of the Colonial Hospital. Now, from 20 to $23^{\text {th }}$ April of 2013, the IHMT will host the " $2^{\text {nd }}$ National Congress of Tropical Medicine" which, despite the "national" epithet, will gather participants from countries other than Portugal, especially from the Portuguese-speaking world, namely from

*Corresponding author: Fernando Teles, Unit of Medical Microbiology, Institute of Hygiene and Tropical Medicine (IHMT), Universidade Nova de Lisboa (UNL), Portugal, Tel: 351 213652600; Fax: 351 213622458; E-mail: fteles@ihmt.unl.pt

Received March 18, 2013; Accepted April 25, 2013; Published April 28, 2013

Citation: Teles FRR, Vieira ML (2013) The Institute of Hygiene and Tropical Medicine of Lisbon and its Research in Medical Microbiology. Clin Microbial 2: 109. doi:10.4172/2327-5073.1000109

Copyright: (c) 2013 Teles FRR, et al. This is an open-access article distributed under the terms of the Creative Commons Attribution License, which permits unrestricted use, distribution, and reproduction in any medium, provided the original author and source are credited. 
Citation: Teles FRR, Vieira ML (2013) The Institute of Hygiene and Tropical Medicine of Lisbon and its Research in Medical Microbiology. Clin Microbial 2: 109. doi:10.4172/2327-5073.1000109

Page 2 of 2

Africa and Brazil. This event will finish the celebrations of the 110 years of the IHMT. It will be an invaluable opportunity to highlight the importance of this exciting branch of Medicine, by publicizing ongoing research lines and hot topics in the field. The health effects from the current extension of excessive urbanization to low-resource regions in under-planned an even chaotic ways and, in parallel, the threaten for the (re)emergence of traditionally confined tropical diseases to the biosocial environments of developed countries underpins the ever-increasing global dimension of Tropical Medicine and, as such, worthwhile expectations from this " $2^{\text {nd }}$ National Congress of Tropical Medicine", to be held in Lisbon.

\section{References}

1. Saraiva JH (1993) História de Portugal [History of Portugal]. Publicações Europa-América, Mem-Martins, Portugal.

2. Abranches $P$ (2004) O Instituto de Higiene e Medicina Tropical. Um século de história 1902-2002 [The Institute of Hygiene and Tropical Medicine. A century of history 1902-2002]. CELOM, Lisbon, Portugal. 